\title{
Monsanto set to back down over 'terminator' gene?
}

[WASHINGTON] The US life sciences company Monsanto is considering delaying the introduction of its controversial germination control technology — tagged by critics as 'terminator' technology - in which crops are genetically modified to destroy their own seeds.

A decision is expected after a meeting today (10 December) between key Monsanto executives and Robert Shapiro, the chairman and chief executive.

The proposed technology has caused anger among farmers in developing countries, who would not be able to save new seeds for replanting if they chose to grow germination control crops. It was developed jointly by the US cotton seed producer Delta and Pine Land Co. - which was taken over recently by Monsanto - and the US Department of Agriculture.

One of the reasons for developing germination control was to protect the intellectual property rights of those developing the seed. A Monsanto working group has been considering how best to respond to the controversy, which has virtually blocked any short-term prospect of improving the company's public image - and that of genetically modified food in general - in developed and developing countries (see Nature 396, 397; 1998).

Some in the company argue that Monsan- to should open a dialogue with its critics, and organize independent research into the implications of germination control technology for all the stakeholders - including the company. The company had previously been asked by signatories to the United Nations Biodiversity Convention to help with their own review of germination control. This exercise, however, has not yet begun.

But any moratorium on introducing germination control would cause internal problems for Monsanto, where such a move is the focus of a vigorous debate. Some staff believe that, far from improving the company's public image, a moratorium might have more damaging consequences in the long term.

They argue that it could be seen as a victory for Monsanto's critics against not just germination control, but the whole of agricultural biotechnology. Such critics include the Rural Advancement Foundation International, based in Canada, and the Research Foundation for Science, Technology and Natural Resource Policy in India.

These are campaigning for a worldwide ban. They achieved some success in October when germination control seeds were banned by the World Bank's agricultural research agency, the Consultative Group on International Agricultural Research. Ehsan Masood

\section{Brazil's scientists fear ministry merger}

[SÃO PAULO] Brazil's Ministry of Science and Technology could be merged with the larger Ministry of Education when the second term of President Fernando Henrique Cardoso begins officially in the new year.

Brazilian scientists fear that the merger could result in reduced funding for research. The plan is one of three options in a report sent to Cardoso by his Minister of Education, Paulo Renato Souza, a former rector of the University of Campinas, who would probably head the resulting superministry.

The second option, which scientists are equally concerned about, is to give the science ministry responsibility for the $\mathbf{5 2}$ federal institutions of higher learning, including all federal universities and some independent centres. The third option would see the current arrangements unchanged.

The science ministry handles about half the total federal spending in research and development. It is currently responsible both for supporting research through grants agencies such as the National Council for Scientific and Technological Development,

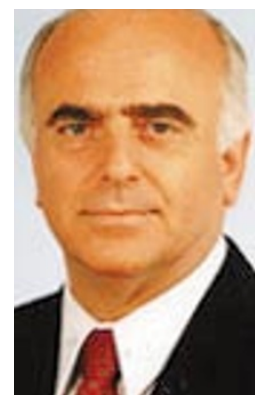

and for directly managing some research centres.

The difficult financial situation facing the federal universities is one reason for the possible changes. According to calculations by the National Association of Souza: tipped to head Directors of Federal new superministry. Institutions of Superior Learning, 94 per cent of the 5.7 billion reals (US $\$ 4.7$ billion) that the Ministry of Education gave these institutions this year was spent on salaries.

Sérgio Henrique Ferreira, president of the Brazilian Society for the Development of Science, thinks that merging the ministries is "madness".

His concern is that it could mean less spending on research. He says both ministries have their own grants agencies, and the government may decide to limit financing of these, arguing that they are duplicating efforts. Ricardo Bonalume Neto

\section{Allow cloning in embryo research, says UK report}

[LONDON] The use of cloning techniques should be permitted in human embryo research under restricted circumstances, recommends a report by the UK Human Genetics Advisory Commission (HGAC) and the Human Fertilization and Embryology Authority (HFEA). But the two groups strongly support the existing government ban on human cloning for reproductive purposes and suggest considering legislation to forbid this.

The report suggests cell nucleus replacement techniques, which "do not involve human reproductive cloning", hold promise for the treatment of serious illnesses, such as Parkinson's and Alzheimer's. The report follows a public consultation exercise launched in January. The HGAC was established in December 1996 as a non-statutory body providing advice to the health and industry secretaries on issues arising from developments in human genetics that have social, ethical and/or economic consequences.

The report, Cloning Issues in Reproduction, Science and Medicine, attempts to draw a fine line between two types of cloning in order to leave the door open for certain research to continue. The document distinguishes between "reproductive cloning or the production of an entire animal from a single cell by asexual reproduction - and therapeutic cloning, applications of nuclear replacement technology which do not involve the creation of genetically identical individuals".

Under existing rules, researchers would be unable to exploit avenues opened up by the recent breakthrough in the culture of human embryonic stem cells (see Nature 396, 104; 1998). The report would extend the current authorized use to include two further purposes for which the HFEA might issue licences for human embryo research - for the development of therapeutic treatments for diseased or damaged organs, and for the development of therapeutic treatments for mitochondrial disease. The report also suggests that, in the light of rapid developments in science and in public attitudes, the situation should be re-examined in five years.

The move follows the release last week of a report on public opinions on human cloning. This concluded that the public felt that humans should never be cloned for reproductive purposes and had reservations about the idea of using cloning technology to create stem cells to make tissues and organs for medical treatment. The Wellcome Trust report found that the public are able to understand the science and grasp the ethical issues and social implications. NatashaLoder 